NBER WORKING PAPER SERIES

\title{
LATIN AMERICA AND FOREIGN CAPITAL IN THE TWENTIETH CENTURY: ECONOMICS, POLITICS, AND INSTITUTIONAL CHANGE
}

\author{
Alan M. Taylor \\ Working Paper 7394 \\ http://www.nber.org/papers/w7394 \\ NATIONAL BUREAU OF ECONOMIC RESEARCH \\ 1050 Massachusetts Avenue \\ Cambridge, MA 02138 \\ October 1999
}

I wish to thank Douglass North, Barry Weingast, Stephan Haber, Anne Kreuger, William Summerhill, and Alan Dye for their comments, and I am grateful to all the conference participants for valuable criticisms on an earlier draft. Any remaining deficiencies in the paper are solely my responsibility. The views expressed herein are those of the authors and not necessarily those of the National Bureau of Economic Research.

(C) 1999 by Alan M. Taylor. All rights reserved. Short sections of text, not to exceed two paragraphs, may be quoted without explicit permission provided that full credit, including $\odot$ notice, is given to the source. 
Latin America and Foreign Capital in the Twentieth Century:

Economics, Politics, and Institutional Change

Alan M. Taylor

NBER Working Paper No. 7394

October 1999

JEL No. E60, F41, F43, G15, N16

\title{
ABSTRACT
}

Latin America began the twentieth century as a relatively poor region on the periphery of the world economy. One cause of a low level of income per person was capital scarcity. Long run growth via capital deepening requires either the mobilization of domestic capital through savings, or large inflows of foreign capital. Latin America's capital inflows were large by global standards at the century's turn, and even up to the 1930s. But after the 1930s, Latin America was not so favored by foreign capital as compared with other peripheral regions-for example, the Asian economies. The Great Depression is conventionally depicted as a turning point in Latin America for commercial policy and protectionism, thus marking the onset of import substitution and a long-run increase in barriers in international goods markets. However, this paper argues that policy responses in the 1930s, and subsequent decades of relative economic retardation, can be better understood as the cause and effect of the creation of long-run barriers in international capital markets. To support this notion, I discuss the quantitative extent of these barriers and their effects on economic growth. As for causality, I argue that the political economy of institutional changes in the 1930s in the periphery might be understood in similar terms to those economic historians have used to discuss the macroeconomic crisis in the core. Such a political-economy model might thus have universal (rather than core-specific) use. It might predict the "reactive" and "passive" responses by periphery countries to external shocks, and the persistence of such shocks in the postwar period. In conclusion, I touch on the important implications of these ideas for the current situation in Latin America, where recent policy reforms aim to undo the last sixty years of isolation and reintegrate Latin America into the global economy.

\author{
Alan M. Taylor \\ Department of Economics \\ University of California \\ One Shields Ave \\ Davis, CA 95616-8578 \\ and NBER \\ amtaylor@ucdavis.edu
}




\section{Economic Growth and Foreign Capital in Latin America since 1900}

To the extent that studies of long-run economic growth have touched on Latin America, it has usually been to depict a peripheral region that has experienced divergence rather than convergence in terms of its income level relative to the core economies. ${ }^{1}$ Inevitably, the region-like the rest of the periphery - could not match the core during the initial burst of the Industrial Revolution in early 19th century Europe and North America. But as global markets developed in the 19th century, and as labor, capital, and technology migrated between countries ever more freely, some economies at the periphery seemed poised to experience a long awaited catching up. ${ }^{2}$ Unfortunately, after 1914, the experience of two world wars and a Great Depression wrecked much of that global economy, and, with it, some argue, the chances for convergence that seemed so likely before 1914. Only recently has a rebuilt global economy started to reemerge from the various crises and aftershocks of the twentieth century. ${ }^{3}$

It is one task of economic historians to document these times, and provide some measure of explanation for the economic, political, and institutional changes that defined them. For variety and volatility of economic experience in this century, no region can surpass - and therefore perhaps no region can be more instructive - than Latin America. Latin America began the twentieth century as a follower, a relatively poor region on the periphery of the world economy, but it ended the twentieth century even further behind the leaders. Examine Table 1 and Figure 1. Today's best estimates of historical trends in income show that in 1900 Latin America's average level of income per capita was well below that of the leading economies of the core, comprising the countries in Europe, North America, and the modern OECD. Some countries in the region were much richer than others, however, and countries with nascent industrial sectors and other signs of modernization had a narrower income gap. For example, the settler economies of Chile and Argentina, and Mexico, which, after sluggish growth for much of the nineteenth century, had grown rapidly in the Porfiriato. ${ }^{4}$

\footnotetext{
${ }^{1}$ The pre-modern origins of this relative backwardness are discussed in Coatsworth $(1993 ; 1998)$ and in the essays in the edited volume by Haber (1997a). For a discussion of the persistence of this backwardness in the mid to late 20th century see Taylor (1998).

${ }^{2}$ A good example would be Argentina, perhaps the most infamous case of economic development potential unfulfilled. See Taylor (1992; 1994b; 1994a).

${ }^{3}$ See Abramovitz (1986), Baumol (1986), Maddison (1991), Sachs and Warner (1995), and Williamson (1996).

${ }^{4}$ As noted by Coatsworth $(1993 ; 1998)$, it is inappropriate to speak of Latin America falling behind in the eighteenth and nineteenth centuries as a uniform and homogeneous feature of the region. Some countries fell far behind, like Mexico and Brazil, motivating the title of Haber (1997a). Others had decent growth performance, compared to much of Europe, if not to the "exceptionalism" of the United States, and even caught up with the core economies, Argentina being just the finest example. Thus, the idea that colonial institutions or factor endowments ensured some deterministic, path-dependent, or path-influenced descent into underdevelopment for the region as a whole requires careful consideration when pursued on a country-by-country basis. Spatial and temporal variation in economic performance was considerable (Engerman and Sokoloff. 1997; North1990). The same is true of the
} 
The overall picture of Latin American development began to change after 1929, and more dramatically after 1950 and during the postwar period. ${ }^{5}$ The region's economies started to experience slower rates of growth on average as compared to the rest of the world, notably relative to the core and to certain fast growing Asian economies; these differential growth rates implied a falling behind, or divergence, in levels of income per capita. In 1900, the Latin American income level was well above that in Asia, and stood at $41 \%$ of the OECD core. In 1950, Latin American GDP per capita was $45 \%$ of the OECD core level and more than three times the Asian average. But by the 1980s Latin America had fallen back to less than one third the OECD level, and was being approached and overtaken by parts of Asia. This 20th century relative retardation and slump in living standards is Latin America's burden of history, and remains a central, burning issue in the region's political, social, and economic landscape. And in countries that have fallen a great distance in economic terms, such as Argentina, once one of the richest economies in the world circa 1900, the burden is great indeed. Unraveling this history and identifying the lessons for today are key challenges for social scientists studying the region.

One obvious way to approach the study of Latin America's growth performance is via the theory and empirics of economic growth. My preference here is to begin with the simplest, and, its proponents still say, the most relevant model of growth as applied to modern experience: the neoclassical theory of growth due to Robert Solow. ${ }^{6}$ It is a theory centered on the accumulation of capital: a low level of income per person is essentially a result of capital scarcity. The production function for output is of the form $\mathrm{Y}=\mathrm{AK}^{\mathrm{a}} \mathrm{L}^{1-\mathrm{a}}$. For a given technology $\mathrm{A}$, and labor force $\mathrm{L}$, improvements in output per worker $(\mathrm{Y} / \mathrm{L})=(\mathrm{K} / \mathrm{L})^{\mathrm{a}}$ are driven by increases in the capital-labor ratio $(\mathrm{K} / \mathrm{L})$.

This process of capital deepening requires, in conventional cases of constant or expanding labor force $\mathrm{L}$, some capital accumulation (increases in $\mathrm{K}, \Delta \mathrm{K}>0$ ). Accumulation occurs via investment ( $\triangle \mathrm{K}=\mathrm{INVESTMENT})$, that is, by the expansion in the quantity of machines, equipment, durable producer goods, land improvements, infrastructure, and so on. ${ }^{7}$

twentieth century, when still more candidates for causes of underdevelopment can be identified, such as the rejection of openness in trade and capital markets as discussed below, despite the region's very open stance since the colonial era.

${ }^{5}$ The standard reference is Díaz Alejandro (1984a; 1984b), who identified 1929 as the major turning point, though not the only one. For an analysis that extends to the present day see Taylor (1998).

${ }^{6}$ The seminal piece is Solow (1956). For a survey of endogenous growth and its empirical relevance see Romer (1994) and Pack (1994). Proponents of the neoclassical model include Mankiw (1995) and Barro and Sala-i-Martin (1995).

${ }^{7}$ The neoclassical model is simple to extend to embrace the notion of human capital accumulation to include skills, knowledge and research. 
Table 1

Income Per Capita, 1900-1990

\begin{tabular}{|c|c|c|c|c|c|c|}
\hline & \multicolumn{6}{|c|}{ GDP per capita in 1980 international dollars } \\
\hline & 1900 & 1913 & 1929 & 1950 & 1973 & 1987 \\
\hline Argentina & 1,284 & 1,770 & 2,036 & 2,324 & 3,713 & 3,302 \\
\hline Brazil & 436 & 521 & 654 & 1,073 & 2,504 & 3,417 \\
\hline Chile & 956 & 1,255 & 1,928 & 2,350 & 3,309 & 3,393 \\
\hline Colombia & 610 & 801 & 975 & 1,395 & 2,318 & 3,027 \\
\hline Mexico & 649 & 822 & 835 & 1,169 & 2,349 & 2,667 \\
\hline Peru & 624 & 819 & 890 & 1,349 & 2,357 & 2,380 \\
\hline Latin American Average & 760 & 998 & 1,220 & 1,610 & 2,758 & 3,031 \\
\hline Asian Average & 485 & 539 & 601 & 505 & 1,061 & 1,952 \\
\hline NICs Average & 492 & 532 & 690 & 545 & 1,939 & 4,444 \\
\hline OECD Average & 1,817 & 2,224 & 2,727 & 3,553 & 7,852 & 10,205 \\
\hline
\end{tabular}

Notes NICs refers to Newly Industrialized Countries; in Maddison's database Taiwan and South Korea.

Source: Maddison (1989).

\section{Figure 1}

Convergence and Divergence of Income Per Capita, 1900-1990

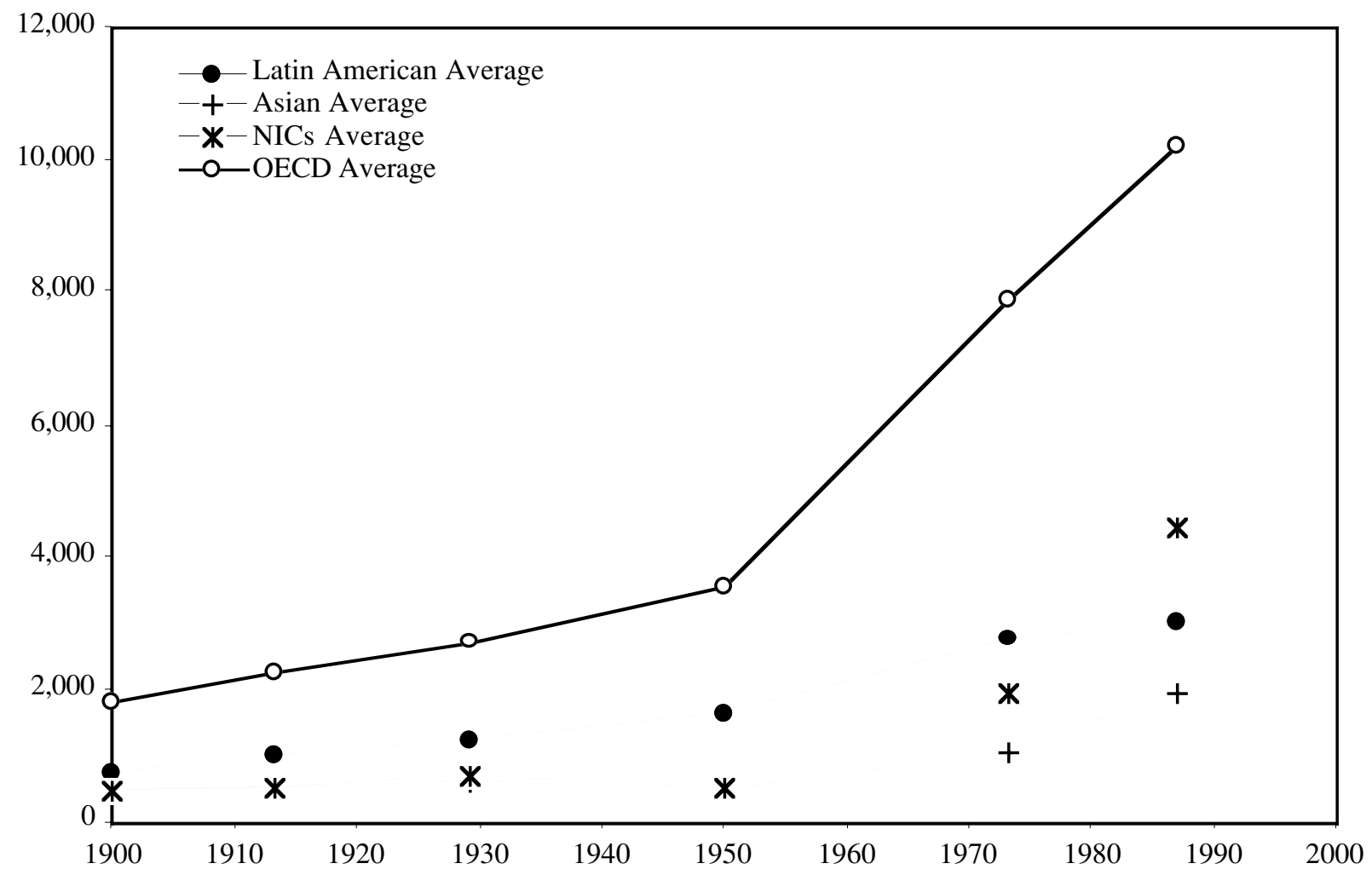

Notes: Chart shows GDP per capita in 1980 international dollars.

Source: Table 1. 
The neoclassical growth model remains one of the most robust explanations for economic growth in the twentieth century, both for wide cross sections of countries, and for Latin America itself. ${ }^{8}$ However, I especially want to appeal to its relevance in a global economy context, with potentially open economies embedded in world markets. Although, in its original form, the model applied to a closed economy, where investment equals savings, its implications for an open economy are easily derived. ${ }^{9}$ In an open economy we must direct our attention to two sources of capital. Accumulation of capital requires either the mobilization of domestic capital through savings, or large inflows of foreign capital. ${ }^{10}$ In simple terms,

\section{INVESTMENT = DOMESTIC SAVINGS + FOREIGN SAVINGS;}

that is, every dollar used in investment has to be financed, either by domestic agents sacrificing consumption and generating a surplus of savings, or by foreigners willing to do likewise.

Thus, if we can explain changes in investment via changes in the incentives or barriers for accumulation, and so account for the responses of domestic and foreign savings, we have a potentially useful theory of long-run growth in a world of open, or even imperfectly open, economies. The simplest data from Latin America's twentieth century history offers at least prima facie evidence that the degree of integration in world capital markets (or, conversely, the extent of barriers or imperfections in such markets) were somehow related to economic growth performance. ${ }^{11}$ Examine Table 2 and Figure 2. For example, during a period of respectable economic performance before the Great Depression, Latin America's capital inflows were large by global standards: very large before 1914, and still substantial even up to the 1930s. But after the 1930s, Latin America received relatively less foreign capital than other peripheral regions, for example, as compared to the Asian economies, most of whom, as we saw above, exhibited much faster postwar economic growth than the Latin American group.

\footnotetext{
${ }^{8}$ Influential empirical papers supporting the model came from Dowrick and Nguyen (1989) and Mankiw, Romer, and Weil (1992). For a large body of empirical results, see Barro and Sala-i-Martin (1995). A thorough sensitivity analysis was offered by Levine and Renelt (1992), emphasizing the robustness of the investmentgrowth relationship. I have found the neoclassical approach useful as a means to study long-run economic growth in the case of Argentina (Taylor 1994b; 1994a) and the region as a whole (Taylor 1998), with similar emphasis on investment as a major source of growth.

${ }^{9}$ A basic open economy model is presented in Blanchard and Fischer (1989).

${ }^{10}$ A national income identity implies that GDP or output $(\mathrm{Q})$ and imports $(\mathrm{M})$ may be allocated for private consumption spending $(\mathrm{C})$, private investment spending $(\mathrm{I})$, government spending $(\mathrm{G})$, and exports $(\mathrm{X})$. Thus $\mathrm{Q}+$ $\mathrm{M}=\mathrm{C}+\mathrm{I}+\mathrm{G}+\mathrm{X}$. Adding to both sides of this equality net factor income from abroad, for simplicity interest payments $(\mathrm{rB})$ from net claims on foreigners $(\mathrm{B})$ bearing interest $(\mathrm{r})$, and rearranging, we obtain an expression for $\mathrm{GNP}(\mathrm{Y}), \mathrm{Y}=\mathrm{Q}+\mathrm{rB}=\mathrm{C}+\mathrm{I}+\mathrm{G}+(\mathrm{X}-\mathrm{M})+\mathrm{rB}$. The latter two terms are the external balance, or balance on the current account, $\mathrm{CA}=(\mathrm{X}-\mathrm{M})+\mathrm{rB}$, equal to the trade balance plus non-trade net income from abroad. Rearranging we obtain the current account identity, $\mathrm{CA}=\mathrm{S}-\mathrm{I}$; $\mathrm{S}$ is savings, $\mathrm{S}=\mathrm{Y}-\mathrm{C}-\mathrm{I}-\mathrm{G}$. An inflow of capital occurs when CA is negative, and we may define foreign savings (or net foreign investment) as $S_{F}=N F I=-C A$. Thus, $I=S+S_{F}$.

${ }^{11}$ For an exhaustive study of long-run movements of capital flows in the world economy, we are indebted here to the work of Twomey (1998).
} 
Table 2

Foreign Investment in Latin America and Asia, 1900-1990

\begin{tabular}{lllllllll}
\hline & 1900 & 1914 & 1929 & 1938 & 1950 & 1970 & 1980 & 1990 \\
\hline Foreign Investment/GDP & & & & & & & & 0.23 \\
\hline Argentina & 4.15 & 2.60 & 1.12 & 0.87 & 0.12 & 0.14 & 0.64 \\
Brazil & 2.55 & 2.96 & 0.92 & 0.70 & 0.18 & 0.17 & 0.32 & 0.36 \\
Chile & 1.88 & 2.11 & 1.56 & 1.63 & 0.49 & 0.38 & 0.27 & 0.40 \\
Colombia & 0.74 & 0.27 & 0.34 & 0.35 & 0.24 & 0.19 & 0.13 & 0.21 \\
Mexico & 1.55 & 1.83 & 1.28 & 0.79 & 0.17 & 0.12 & 0.23 & 0.32 \\
Peru & 1.78 & 1.21 & 0.64 & 0.46 & 0.22 & 0.22 & 0.32 & 0.48 \\
Uruguay & 3.14 & 1.62 & 0.67 & 0.59 & 0.18 & 0.13 & - & 0.31 \\
Venezuela & 2.52 & 0.98 & 1.05 & 0.73 & 0.55 & 0.36 & 0.32 & 0.47 \\
\hline India & 0.25 & 0.34 & 0.30 & 0.45 & 0.08 & 0.18 & 0.11 & 0.25 \\
Indonesia & 0.62 & 0.95 & 1.11 & 1.29 & - & 0.29 & 0.66 & 1.68 \\
Malaysia & - & 1.48 & 1.04 & 0.79 & - & 0.33 & 0.29 & 0.58 \\
Philippines & - & 0.17 & 0.22 & - & - & 0.34 & 0.29 & 0.58 \\
Thailand & - & 0.38 & 0.35 & 0.30 & - & 0.16 & 0.21 & 0.33
\end{tabular}

Notes: For Argentina and Uruguay, 1990 column shows 1989 data.

Source: Twomey (1998).

Figure 2

Foreign Investment in Latin America and Asia, 1900-1990

Foreign Investment as a share of GDP

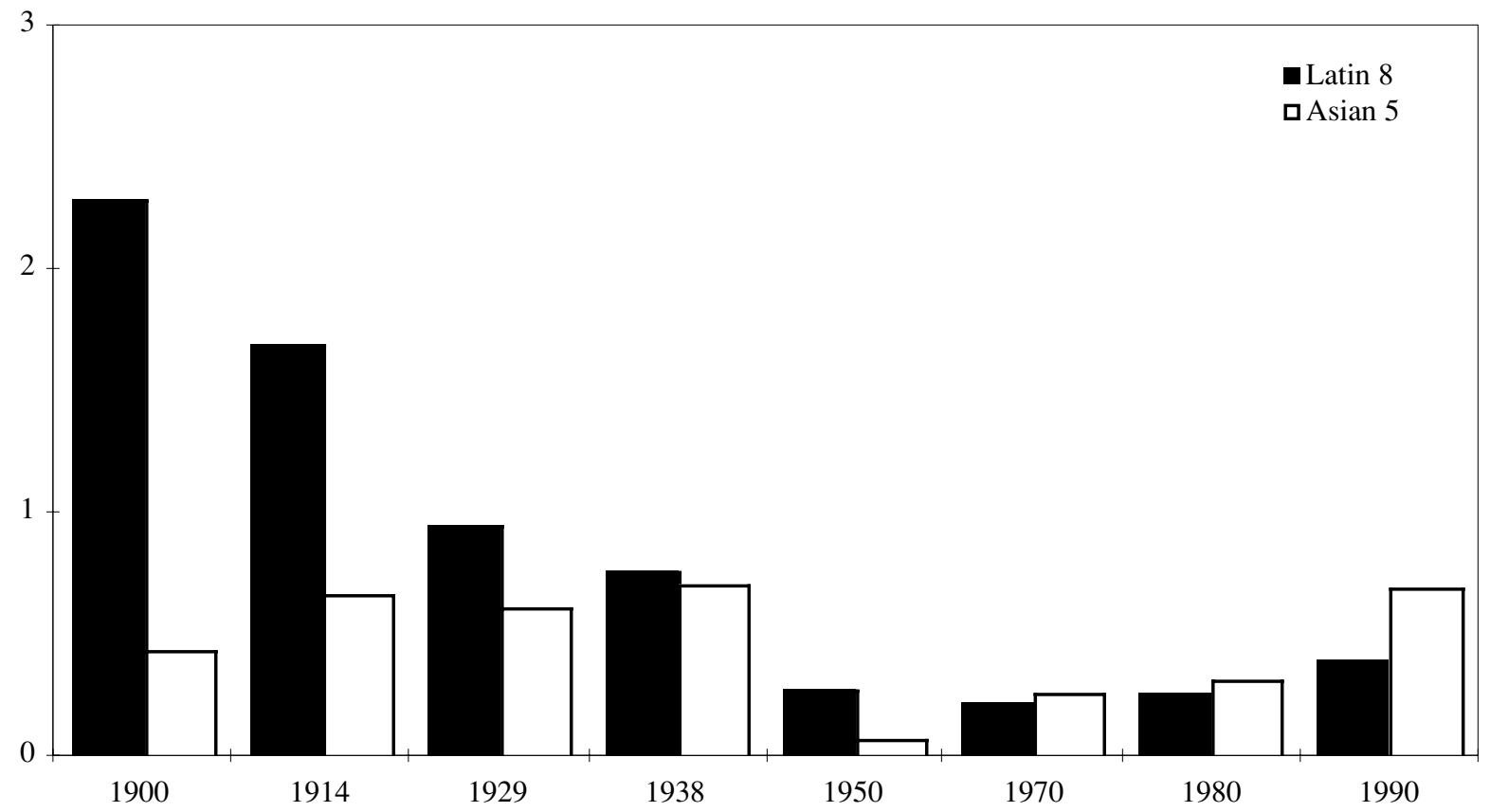

Source: Table 2, simple unweighted averages. 
From this introductory review of the macroeconomic historical evidence two things stand out. First, that since the early years of the century Latin American growth performance has been disappointing, exhibiting retardation relative to the core, especially after the 1930s. Second, we also find evidence that foreign capital, though it retreated in importance in many countries in the autarkic years after the 1930s, apparently retreated further and faster in the case of Latin America. What remains to be asked is what causal connections exist between these two correlated events. My analysis centers on an examination of interventions in international markets that affected the integration of Latin America in the global economy. Since my focus is the capital market, it is natural to begin with a discussion of the emergence of explicit capital controls. In the next section I trace the emergence of capital controls in the 1930s, and their subsequent evolution and pervasive effects on investment prices and quantities — and thus, growth — in the postwar period.

\section{The Great Depression as a Watershed in Capital Markets}

The Great Depression is conventionally depicted as a turning point in Latin America for commercial policy and protectionism, and as marking the onset of import substitution and a long-run increase in barriers in international goods markets. This perspective is evident in almost all works, and the discussion of trade distortions is now standard textbook material. ${ }^{12}$ I will not argue that this description is incorrect, but rather incomplete, and that a complementary analysis exists with a quite different emphasis on capital markets. Moreover, in terms of economic theories of long-run growth, this new emphasis offers what I will argue is a clearer and more plausible explanation for the dynamic losses involved in the relative slow-down and divergence of the region's economies. ${ }^{13}$

Thus, this paper argues that the policy response of the 1930s, and the subsequent economic retardation, can be better understood as the cause and effect of the creation of long-run barriers in international capital markets. The argument will proceed in the present section in three parts.

Firstly, I will discuss the emergence of capital controls in the 1930s as the prototypical or archetypal market intervention that set the stage for later distortions in the capital market price system in Latin American economies. This requires an understanding of the gold standard system that collapsed in the 1930s, and the macro-policy responses that characterized government reactions throughout the region and, for comparison, the world.

Secondly, I will trace the region's subsequent postwar distortions that descended from the interventions of the 1930s and evolved within a macro-policy framework that had a high tolerance for price distortions at the international level. The evidence here will review data on the black

\footnotetext{
${ }^{12}$ See for example Fishlow (1971), Thorp (1992), Cardoso and Fishlow (1992), Cardoso and Helwege (1992), Edwards (1995), and Bulmer-Thomas (1994; 1996).

${ }^{13}$ In contrast, trade theories offer only an explanation for static losses.
} 
markets for currency, tariffs, and investment goods prices, to get a general picture of barriers to accumulation.

Thirdly, I will review analysis of the growth or welfare implications of these distortions. The overall aim here is to show not only that distortions existed, but that they had negative effects that were quantitatively and statistically significant. Here I will have time for only a brief survey of the enormous literature on this topic.

\section{Capital Controls in the 1930s}

One almost universal feature of the global economy of the late 19th century was the virtually complete absence of capital controls. Indeed free migration of labor, and, for the most part, a liberal regime of low trade barriers was the norm, albeit with some exceptions. This laissez faire economic orthodoxy reached full expression in capital markets and in the financial world, and in the form of monetary standards built around the gold standard, fixed exchange rates, free convertibility, and unfettered movement of capital. ${ }^{14}$ In this "golden age" did Keynes' stereotypical pajama-clad investor consume breakfast in bed in London whilst telephoning a broker to bid his investments move hither and yon around the world with out let or hindrance. ${ }^{15}$

Governments' believed their credibility rested on their ability to adhere and sustain this system, so that even during World War I, the general belief was that return to gold was paramount, and that the capital controls enacted by various countries, especially the belligerents, were merely a temporary expedient. ${ }^{16}$ The literature on the collapse of the interwar gold standard indicates that various forces - including crises of expectations, asymmetries in the equilibrating mechanism, recent memories of hyperinflation in some countries, increased speculation in expanding future markets, and temptations for competitive devaluation — all rendered the gold standard "unsafe for use" in the 1920s and 1930s, at least when governments came under increased pressure after 1929 to engage in macroeconomic management to stave off the threat of deflation and depression. ${ }^{17}$

In such an imploding world economy, countries on the brink of a crippling gold outflow had no choice but to take a decision to "break the rules of the game" (or lose all their gold reserves and have the decision made for them sooner or later). They could turn to a blunt and noninstantaneous instrument like devaluation to salvage their external balances, or, in more desperate straits, they could end gold drain by fiat, by imposing capital controls. This breakdown of the old regime began in the core (with Britain's departure from gold) in late 1931. As other countries followed, some chose devaluation, mostly the countries of northwest Europe and its new world

${ }^{14}$ See Edelstein (1982), Eichengreen (1992; 1996).

${ }^{15}$ Keynes, quoted in Yeager (1976).

${ }^{16}$ Einzig (1934), Eichengreen (1992; 1996), Obstfeld and Taylor (1998).

${ }^{17}$ Eichengreen (1992; 1996), Temin (1989). 
Table 3

Latin America's Adoption of Capital Controls as of 1939

\begin{tabular}{|c|c|c|c|c|c|c|c|}
\hline \multirow[b]{2}{*}{ Country } & \multicolumn{3}{|c|}{ Exchange Control, 1930-39 } & \multicolumn{3}{|c|}{ Free Market Activity } & \multirow{2}{*}{$\begin{array}{l}\text { Black } \\
\text { Marke }\end{array}$} \\
\hline & None & Begun & Abolished & Tolerated & Controls & None & \\
\hline Argentina & & 1931 & & & $\cdot$ & & \\
\hline Bolivia & & 1931 & & & • & & • \\
\hline Brazil & & 1931 & & & & • & \\
\hline Chile & & 1931 & & & • & & \\
\hline Colombia & & 1931 & & & & - & - \\
\hline Costa Rica & & 1932 & & & • & & \\
\hline Cuba & • & & & • & & & \\
\hline Dominican Republic & • & & & • & & & \\
\hline Ecuador & & 1933 & 1937 & • & & & \\
\hline El Salvador & - & & & • & & & \\
\hline Guatemala & • & & & • & & & \\
\hline Haiti & • & & & • & & & \\
\hline Honduras & & 1934 & & & & - & \\
\hline Mexico & • & & & • & & & \\
\hline Nicaragua & & 1932 & & & • & & \\
\hline Panama & • & & & • & & & \\
\hline Paraguay & & 1932 & & & & & \\
\hline Peru & - & & & - & & & \\
\hline Uruguay & & 1932 & & & & - & \\
\hline Venezuela & & 1936 & & - & & & \\
\hline
\end{tabular}

Source: Bratter (1939).

offshoots; some chose controls, chiefly Germany and its trading partners in central and eastern Europe. In Latin America, as elsewhere in the periphery, crisis struck much earlier, and many economies had abandoned the gold standard with devaluations in 1928 and 1929, as their terms of trade collapsed and payments problems became severe. By the early 1930s, as problems continued, many were ready to go further and combine devaluations with capital control measures.

Table 3 illustrates the timing of capital controls in Latin America in the 1930s. A clear dichotomy exist between a group of controllers, including many of the larger countries of the region, notably the Southern Cone (Argentina, Brazil, and Chile) and a set of smaller countries in the region, especially in Central America, all of whom eschewed controls. This division is often referred to as the partition of the region into "reactive" and "passive" countries, as they were termed by Díaz Alejandro.

Usually this classification is seen as being principally derived from a response to external political and economic forces. ${ }^{18}$ For example, consider a small Caribbean or Central American country subject to U.S. foreign policy pressure, perhaps in the form of gunboats, and reliant heavily on U.S. export markets and finance. This country might be afraid to devalue and enact controls,

${ }^{18}$ Díaz Alejandro (1984b). 
fearing retaliatory action by the dominant military and economic power in the hemisphere. Indeed, past experience had shown many countries the lengths to which the U.S. might go to protect its overseas economic interests. Conversely, larger countries or those more distant from the U.S. (hence, more powerful and independent), could more easily make the choice to "break the rules" and deviate from the orthodoxy, even before the U.S. itself did in 1933.

This depiction of Latin American outcomes as being heavily dependent on external forces is surely relevant in a setting of small, open economies at the periphery, all of whom have little power to affect global political or economic conditions, most of which they must take as given. ${ }^{19}$ And there are certainly some countries for which the external political costs of policy deviation were very influential - for example, Cuba or Mexico or Central America under the influence of U.S. foreign and economic policy. However, as I will argue later, leaving the story here may be too restrictive and may lean too far toward monocausality in emphasizing external forces as the main determinant of outcomes in the region.

\section{Postwar Distortions}

Why should events of the 1930s interest us when considering the determinants of long-run economic performance over several decades in Latin America? I will argue that they are of crucial importance, as one can understand by posing a different question. Was the reactive and passive response of Latin America's economies temporary or persistent? If the answer is that they were persistent then there is something to suggest that the immediate response of the economies to the 1930s crisis was not merely a response to what were transient external economic shocks, but also revelatory as regards some other characteristics of these countries.

Persistent they were, as we can detect from the nature of postwar distortions in these economies. After the 1930s the structure of exchange controls varied greatly, and in some places tariffs replaced or complemented multiple exchange rate regimes. The extent of controls is therefore best evaluated using multiple criteria relevant to the capital market which pick up various kinds of distortions, such as black-market premia on the currency, the extent of tariffs, distortions to relative capital prices, and currency depreciation.

What I claim is that even late in the postwar period, and despite numerous policy changes along the way by various countries, the basic passive-reactive categorization proposed by Díaz Alejandro for the 1930s remained relevant. Still decades later the larger and more southerly countries tended to be the ones with large distortions and interventions; typically, the passive

\footnotetext{
${ }^{19}$ One can envisage a few exceptions, for example Brazil might have some market power in coffee.
} 
Table 4

Distortions in Latin America and Elsewhere, 1970-1990

\begin{tabular}{lcccc}
\hline & $\begin{array}{c}\text { Black Market } \\
\text { Premium on } \\
\text { Currency }\end{array}$ & $\begin{array}{c}\text { Own-Weight Tariff } \\
\text { Incidence }\end{array}$ & $\begin{array}{c}\text { Log Relative Price } \\
\text { of } \\
\text { Capital Goods }\end{array}$ & $\begin{array}{c}\text { Rate of } \\
\text { Depreciation of } \\
\text { Currency }\end{array}$ \\
\hline All Countries & 0.27 & 0.17 & 0.44 & 0.10 \\
Asia Pacific & 0.06 & 0.13 & 0.23 & 0.02 \\
Latin America & 0.26 & 0.22 & 0.27 & 0.37 \\
Southern Cone & 0.32 & 0.27 & 0.19 & 0.60 \\
\hline
\end{tabular}

Notes and Source: See Taylor (1998).

countries of the 1930s, the smaller and more northerly group of countries, had the smaller distortions. The quantitative evidence appears in Table 4, drawn from another paper. ${ }^{20}$

The persistence in policy response should not be too surprising if the response, instead of being merely a reaction to fleeting adverse external conditions in the crisis of the 1930 s, did indeed reflect deeper characteristics of the polity in each country, that is, internal conditions less subject to change. There are clear candidates here in the sphere of domestic political conditions. Examples would include: a country's degree of democracy; the accessibility or plurality of the government system, especially for weak or marginal groups; the centralization of power; the general education of the populace as it might affect demands for representation; and so on. All of these factors could accentuate political pressure for active intervention.

Moreover, we have some reason to suspect that all of these characteristics more or less fit into the story, within and beyond Latin America. Arguably, the southern cone countries, by the early twentieth century, did tend to more closely resemble the core countries, with more developed educational systems, a more developed democratic tradition, and a broader franchise. In the history of countries like Argentina, Chile, and Brazil these populist social and political pressures figure heavily. Yet such pressures should also have had economic consequences, especially in the policy vacuum of the 1930s following the collapse of the gold standard, and, we guess, in line with the theories already suggested for these forces as they worked in the core. Conversely, conventional wisdom suggests, countries in Central America experienced much less populist pressure, had on average less broadly representative government, and so on-predicting, based on our working theoretical hypotheses, that they would have had less inclination toward interventions and controls to temper external forces in the capital market.

Let us take the argument a stage further, for a global comparison, and use an extreme example for illustration. We can recognize a marked contrast between the populist pressure

\footnotetext{
${ }^{20}$ However, this finding does not contradict earlier quantitative and historical description of the nature of policy choices in Latin America since the onset of inward-looking strategies in the 1950s. Always in the vanguard of such policies were countries like the Southern cone group.
} 
generated in, say, post-1945 Argentina, by the descamisados, assorted unions and corporatists groups, and all the other lobbies, compared with, say, the almost complete absence of protests, populism, and political turmoil in a state such as Singapore. The same contrast might well hold for almost any comparison of the reactive, and even some in the passive group, in Latin America and the East Asian fast-growing economies (South Korea, Taiwan, Hong Kong, and Singapore). Thus the perspective advanced here, also has a potential power to explain policy outcomes in Latin America as compared to its usual developing country benchmark, the more economically successful and more outward-oriented countries of East Asia.

What remains is to see how feasible it is to try to measure and quantify these differences in politics and regimes, and to see whether the putative relationship with policy outcomes has empirical content. But first, we will spend a moment just to confirm the ultimate claim that these interventions and distortions, as they resulted from the domestic political process, did indeed have implications for economic performance.

\section{Growth Implications}

The discussion of the role of capital market interventions and their resulting price distortions would be irrelevant if it could not be shown that such policies had implications for historical development experience. The literature on the role of such distortions as a detriment to growth is now very extensive and does not require extensive recapitulation here. ${ }^{21}$ It suffices to record here the relevant results as applied to the Latin American case. In another paper devoted to this topic, and covering experience since the 1930s, I have examined the size of distortions, and, for the 1970s and 1980s, used econometric estimation to figure their importance for investment and economic growth. ${ }^{22}$

Table 4 holds the comparative data that show that Latin America's distortions were much higher than the Asian group in almost all areas. In the same paper I also showed that this went along with lower investment rates and growth rates in Latin America versus Asia: for example, between 1970 and 1990, investment rates in the two regions were $16 \%$ versus $23 \%$ and growth rates of per capita income $0.5 \%$ versus $3.4 \%$. Econometric counterfactual analysis (not repeated here) showed that distortions had a paramount and robust role in depressing Latin America's rate of accumulation of capital, and hence the rate of growth. All of the difference in investment rates can be explained by this exercise, and, thus, about half of the implied difference in growth rates. ${ }^{23}$

\footnotetext{
${ }^{21}$ See for example De Long (1991), Easterly (1993), Edwards (1992), and Jones (1994). All these studies find a strong negative correlation between price distortions on the one hand, and investment or growth on the other.

${ }^{22}$ See Taylor (1998).

${ }^{23}$ It bears repeating that I am not in search of a monocausal explanation here, but I do claim any factors that can explain between $50 \%$ and $100 \%$ of Latin America's retardation in the growth of output and capital demands at least some attention.
} 
The purpose of this brief section is merely to motivate the search for the underlying determinants of these detrimental policies in the political and institutional environment of the countries themselves. It matters because the reference group, the Asian group, as has been pointed out before, though initially subject to the a similar inward-looking response as almost every other economy in the 1930s, 1940s, and 1950s, did eventually reform and embrace policies favoring integration into the global economy. Latin American countries, almost without exception, did not. ${ }^{24}$ Objective distortion measures for the Asian group were little different than the Latin group in the early postwar period. ${ }^{25}$ But after 1970 the differences were marked, as were the different economic outcomes. The bigger question is how we identify the institutional obstacles that prevented Latin America from taking the same route to early economic reforms, reforms that are now happening belatedly and, some critics suggest, only half-heartedly. ${ }^{26}$

\section{Summary}

Given space constraints, the preceding section has reviewed the evidence on distortions and growth since the Great Depression. The hope was to persuade the reader, first, that distortions existed, and, second, that they mattered for long-run economic outcomes. A purely economic analysis might end here, with an appeal to theory, and further appropriate testing for robustness, to claim that distortions were somehow causally responsible for the growth outcome. Indeed this has been the ending point for many such studies, so many that the point is widely accepted. ${ }^{27}$

Such an end point is still unsatisfying, for it begs further questions: why did such distortions emerge in the first place, and why did they persist in the long run? These are implicitly comparative puzzles, of course, with great bearing on the question of why Latin America's twentieth century economic institutions have evolved in such a peculiar fashion as compared to other regions of the world. To answer them we need to fashion some tool for exploring the political economy of policy choice in the Great Depression and in the decades that followed.

\section{Political Factors in the Core and Periphery}

Beginning with the collapse of the gold standard, Latin America's macropolicy response began its long and wayward course, so it is natural to start there. In fact, the good news is that macroeconomic historians already have proposed some models for understanding the nature of

\footnotetext{
${ }^{24}$ It is the exception that proves the rule, perhaps. The exception might be Chile, which did engage in freemarket reforms in the 1970s. However, this was under a military dictatorship that aimed to squash populist pressures, and resembling, therefore, the more centralized and autocratic pressures at work in Asian regimes.

${ }^{25}$ See Taylor (1998).

${ }^{26}$ See Edwards (1995).

${ }^{27}$ See for example the earlier cited studies: De Long (1991), Easterly (1993), Edwards (1992), and Jones (1994).
} 
macropolicy responses in the 1930s. The model revolves around a simple policy "trilemma" that confronts policymakers who face pressures from different constituencies to achieve three mutually inconsistent goals: exchange rate stability, free capital mobility, and macroeconomic stability (e.g., "full employment"). Such a theory have been applied mostly to understand the response of the core economies, notably Britain, Germany, France, and the United States, plus certain other European and New World economies. ${ }^{28}$

The conjecture I wish to advance is that the political economy of institutional changes in the 1930s in the periphery might be understood in more or less the same terms economic historians have used to discuss the macroeconomic crisis of the gold standard in the core. Such a politicaleconomy model might thus have universal, global (rather than core-specific) value if it can predict the "reactive" and "passive" responses by periphery countries to external shocks. The conjecture seems like a desirable but difficult goal, though in the present paper I can only sketch some ideas and implications, and fall far short of proof. Should the conjecture apply, it would lend more credibility and applicability to the theory, and would have intrinsic methodological appeal, as we place a premium on models that apply to a class of different cases, rather than requiring a different story for each and every situation.

The model is simply laid out. At the start, under a fixed exchange-rate system, like the gold standard, and in an open economy with free capital mobility, policymakers have no power to use monetary policy as an instrument for the manipulation of the domestic economy. Essentially, the monetary policy is endogenous, as domestic interest rates are set by the world market, and via the arbitrage actions of the capital. Any attempt to move the interest rate is futile: it would entail the loss (or gain) of reserves for a temporary (if any) decline (respectively, rise) in domestic interest rates. Thus was monetary policy depoliticized under the gold standard: no objectives were attainable so the instrument was never touched.

For the core at least, all this changed, it is argued, with the onset of the Great Depression, and, preceding it, a gradual but profound change in the power of various constituencies in the political process, notably the influence of working class groups and parties. Gold standard orthodoxy had satisfied the interests of bankers, financiers, and others, but ill-served the working class; in times of boom abroad or bust at home, no attempt could be made by the authorities to temper the force of recession by easy monetary policy. Consequently, unemployment in crises could be severe, yet be dismissed as beyond the scope of national economic policy. Such a view is not taken today, and the turning point was the 1930s. Governments broke the "rules of the game" and allowed monetary policy into their toolkit. This could happen in two ways: capital controls could be admitted, allowing monetary policy discretion without risk of capital movement; or a

\footnotetext{
${ }^{28}$ See Eichengreen (1996) and Obstfeld and Taylor (1998).
} 
floating exchange-rate system could be introduced, allowing monetary policy to act freely without a need to defend the parity.

In Europe and the United States, the applicability of this kind of model to historical events in the core economies is now accepted, based on the seminal work of authors such as Peter Temin and Barry Eichengreen. ${ }^{29}$ Democratic political institutions and the new broadening of the franchise were realities in the early 20th century, likewise the growing influence of the poor and working class groups. Only a few economies clung to the gold standard longer than was necessary in the 1930s - the gold bloc of France, Netherlands, and Belgium — and they paid a heavy price in a world of deflation and economic collapse. By the 1936, all core economies had given up the parity. ${ }^{30}$

But what can we say about events at the periphery? Might such a model, if it were a more general model, not also illuminate the various responses of different countries outside the core? In particular, can it help us understand the evolution of policies and economic growth in Latin America? The idea is in marked contrast to explanations based on external conditions: older schools of thought, such as dependency theory and structuralism, have looked almost exclusively at external macroeconomic forces as being behind the ruin of the periphery. ${ }^{31}$ More recent historical critiques have challenged these approaches, not just for theoretical and empirical shortcomings, but also for a lack of attention to microeconomic, institutional, and political developments internal to Latin America as an explanation for economic outcomes in the long run. ${ }^{32}$ A reordering of research directions is warranted, some argue, to more accurately portray Latin American economic history as a process conditioned by both internal and external forces.

In this spirit, I will venture to suggest that we reconsider the history of macroeconomic policy in the same way, and try to understand the 1930s policy responses of the economies as being potential driven by internal forces. We have seen that there is a theory we can even take off the shelf: we can apply the same analytical devices to describe the core economies. Their treatment suggests that the path chosen by policymakers is explicable in terms of domestic politics. Thus, for example, the theory we have predicts that rising democratic and pluralistic forces raised the likelihood of deviation from the gold standard. ${ }^{33}$ The question for Latin American history is this: can we detect such a link between domestic politics and policy outcomes? And, does it matter for only the 1930 s, or can it also explain policy persistence?

${ }^{29}$ For more detail see Eichengreen (1992) and Temin (1989).

${ }^{30}$ See Eichengreen (1996) and Obstfeld and Taylor (1998).

${ }^{31}$ See Cardoso and Helwege (1992) for an overview of such ideas associated with the Structuralists.

${ }^{32}$ For a trenchant critique see Haber (1997b).

${ }^{33}$ An example would be France in the 1920s, and the demands of various class groups that the fiscal burden be shifted, producing stalemate and delaying a return to the gold standard. Another example would be Britain in the 1920 s, and the miners' strikes and general strikes in response to the strictures of a tight monetary policy designed to deflate the price level towards its purchasing-power-parity level with the pound overvalued at resumption. 
In order to explore this hypothesis we need to quantify two features of economic developments and political institutions since the 1930s. First, we need measures of policy response at various junctures, such as capital controls, black market activity, and price distortions. Second, we need the much more subjective measures of political institutions that will tell us something about how susceptible economic policies were to broad democratic forces in general, and the influence of less-privileged groups in general. To make the challenge harder, we need these measures for many countries at many different points in time.

In terms of measuring policies we have already seen a wide range of data. We can see which countries enacted controls in the 1930s, and how these policies evolved into multifaceted distortions by the 1950s, 1960s, and beyond. ${ }^{34}$ Thus we can provide measures of policy response. In terms of measuring political institutions we are on more difficult ground, as expected. However, the results of the Polity project can be employed here. ${ }^{35}$ The Polity database supplies annual data series on regime type and political authority for 177 countries since 1800, series that include measures of democracy, autocracy, the breadth of the political process and its accessibility to various groups, and so on. Combining all the political and economic data, we can try to explore how political conditions shaped macropolicy response in the 1930s and after.

Looking first at the 1930s, if we seek evidence that the core-type of gold-standard political economy model might function as a model for the periphery then we need evidence that passive and reactive states were distinguished by very different internal domestic political characteristics. Since reactive in Latin America is synonymous with capital controls, it suffices to look for systematic differences between control and non-control countries in Latin America. Table 5, Panel (a), shows that the Polity III database can detect a difference between the two groups, and one consistent with the theory. The passive non-control countries were more autocratic and centralized, and had less constraint on executive power, less regular and competitive participation in the political process, and less democratic regimes. All of this left them less exposed to populist pressure in the theory. Conversely, the reactive group had much more scope for popular pressure to feed into the political and economic decision making process. Panel (b) confirms the relationship by looking not at means, but at correlations amongst the variables in the Latin American sample.

\footnotetext{
${ }^{34}$ The application of the trilemma idea to Latin America may appear not so straightforward. We have noted already that for many countries in the region, an initial attempt to resolve the trilemma through devaluation proved insufficient, and many then turned to controls as an auxiliary device. In general, the trilemma must be seen as encompassing "mixed strategies" of this sort: partial use of both devaluation and capital control tools may, jointly, suffice to relieve tensions. It is a matter of judgment, then, to decide which constraint is really binding, and therefore which policy move was critical. Implicitly, I am taking the position that if, in the 1930s, the floating rate proved insufficient to solve the tensions, perhaps because it was a dirty float as was often the case, and controls were in the end necessary, then this constituted a controls-based strategy, as opposed to a true floating rate strategy with free capital mobility.

${ }^{35}$ See Jaggers and Gurr (1995). The data was downloaded from ICPSR, file 6695.
} 
Table 5

Politics and Capital Controls in Latin America in the 1930s

(a) Political Variables for Control and Non-Control Countries in Latin America

\begin{tabular}{lrrrrrr}
\hline CONTROL & AUTOC & DEMOC & XCONST & PARREG & PARCOMP & CENT \\
\hline 0 & 4.00 & 1.63 & 2.50 & 2.63 & 1.88 & 1.25 \\
1 & 3.25 & 2.92 & 3.33 & 3.33 & 3.17 & 1.17 \\
\hline
\end{tabular}

(b) Correlations of Political Variables with Controls and Devaluation in Latin America

\begin{tabular}{|c|c|c|c|c|c|c|c|c|}
\hline & AUTOC & DEMOC & XCONST & PARREG & PARCOMP & CENT & CONTROL & DEVAL \\
\hline AUTOC & 1.000 & & & & & & & \\
\hline DEMOC & -0.712 & 1.000 & & & & & & \\
\hline XCONST & -0.721 & 0.730 & 1.000 & & & & & \\
\hline PARREG & 0.217 & 0.322 & 0.345 & 1.000 & & & & \\
\hline PARCOMP & -0.419 & 0.588 & 0.554 & 0.588 & 1.000 & & & \\
\hline CENT & 0.064 & -0.185 & 0.000 & -0.016 & 0.091 & 1.000 & & \\
\hline CONTROL & -0.156 & 0.251 & 0.289 & 0.339 & 0.496 & -0.068 & 1.000 & \\
\hline DEVAL & -0.413 & -0.052 & 0.112 & -0.593 & 0.338 & 0.322 & -0.092 & 1.000 \\
\hline
\end{tabular}

(C) Regression model: Controls and Devaluation with Political Variables in Latin America

\begin{tabular}{|c|c|c|c|c|}
\hline & CONTROL & CONTROL & DEVAL & DEVAL \\
\hline PARCOMP & $\begin{array}{r}0.19 \\
(2.42)\end{array}$ & - & $\begin{array}{r}3.78 \\
(1.14)\end{array}$ & - \\
\hline DEMOC & - & $\begin{array}{r}0.05 \\
(1.10)\end{array}$ & - & $\begin{array}{c}-0.24 \\
(0.16)\end{array}$ \\
\hline R SQUARED & .246 & .063 & .114 & .003 \\
\hline
\end{tabular}

Notes and Sources: Political variables are for 1929 and are taken from the Polity III database. AUTOC is a measure of autocracy, from 0 to 10; DEMOC is a measure of democracy, from 0 to 10; XCONST is a measure of constraints on the executive from 1 (unlimited authority) to 7 (executive party or subordination); PARREG is a measure of the regulation of participation in the political process from 0 (unregulated) to 5 (institutionalized); PARCOMP is a measure of the competitiveness of participation, from 0 (unregulated) to 5 (competitive); CENT is a measure of centralization of state authority, from 1 (unitary) to 3 (federal). The economic variables are from Bratter (CONTROL) and the League of Nations Yearbooks (DEVAL). CONTROLS takes the value 1 if controls were applied in the $1930 \mathrm{~s}, 0$ otherwise. DEVAL is equal to the percentage devaluation of the currency relative to gold parity as of January 1935.

The correlations tell a similar story, and help us identify strongly collinear characteristics: e.g., autocracy is almost exactly opposite to democracy in many cases. Panel (b) also looks at the correlation of the political variables with the economic policy outcomes, both controls the extent of devaluation. For the most part, the clearer correlations are between political variables and control outcomes: this is not surprising, as almost all countries were forced to devalue it was only with respect to capital controls that differences emerged. Panel (c) examines the statistical fit of the relationship for the most promising candidates, the variables PARCOMP and DEMOC. The latter, a democracy measure, fares poorly, but the former does better, especially in explaining the imposition of controls, the definitive policy of the reactive group of countries. This is good news for the theory, for in the Polity III database, the PARCOMP variable measures "the extent to which 
Table 6

Politics and Distortions in Latin America and the Asian NICs in 1970

\begin{tabular}{lcccccrr}
\hline & DEMOC70 & PARCOMP70 & PARCOMP29 & BMP70 & OWTI & OWQI & PPI70DEV \\
\hline NIC3 & 1.00 & 2.00 & - & 0.05 & 0.08 & 0.16 & -0.17 \\
LATIN & 2.64 & 2.45 & 1.88 & 0.21 & 0.17 & 0.22 & -0.02 \\
$\begin{array}{l}\text { PASSIVE } \\
\text { LATIN } \\
\text { REACTIVE }\end{array}$ & 3.75 & 3.00 & 3.17 & 0.34 & 0.23 & 0.28 & 0.20 \\
\hline
\end{tabular}

Notes and Sources: For classification, NIC3 is South Korea, Taiwan, and Singapore (Hong Kong is omitted as political variables are not available for this non-sovereign state), LATIN PASSIVE are the group of countries who did not enact controls in the 1930s, LATIN REACTIVE is the group that did based on Bratter. DEMOC70 is the democracy measure (0 to 10) for 1970, PARCOMP70 and PARCOMP29 are the competitiveness of participation measures ( 0 to 5) for 1970 and 1929, and these three variables are from Polity III. BMP70 is the black market premium in 1970, OWTI the tariff incidence, OWQI the quota incidence, and PPI70DEV the percentage deviation of the relative price of investment goods from the world level, and these distortion measures are from Sachs and Warner.

non-elites are able to access institutional structures of political expression." I think this variable most succinctly summarizes the extent of sociopolitical tensions that lie at the heart of the Eichengreen model of reaction against the gold standard in core economies as it was driven by newly enfranchised groups ready and able to challenge the old orthodoxy. The finding here is that similar forces are discernible in a set of peripheral economies too. Although quantitative and significance appears weak at present, the results are novel in that they support this well established theory from the core in a new geographical setting, and they might be viewed as surprisingly good since the political data are essentially so subjective and prone to error. It is also reassuring that although the political variables were collected for a project to track democracy and peace, they do in fact have some relation to other political outcomes, here in the realm of economic policy.

It might be satisfactory if the story ended here, but we can also ask the data to tell us much more. We know that the reactive policies of the 1930s persisted for decades. A tougher test is the following: can the political data give any prediction of economic policy outcomes in the postwar era? Table 6 suggests they can, and still in line with the theory. Moreover, at the later date we can start to make some inter-regional comparisons. The table rows show three groups of countries that are of interest circa 1970. First, we have the three successful fast-growing Asian NICs. Then we have the historically passive Latin American group, and finally the reactive Latin American group, with the distinction here based on 1930s policy response. It is evident that reactive policies tended to persist: the various distortion measures are clearly higher for the reactive group. Distortions are very low in the NIC3 group as expected. As for the relationship of these economic policy outcomes, it is apparent that the subsamples more prone to populist pressures do experience more distortions: less democratic and less competitive participation in the political process of the NICs is the 
accompaniment to non-interventionist policy. Passive Latin American countries come next with more populist pressures, and more intervention. Lastly the reactive group has high levels of democracy and competitive participation in the political process. Following our previous finding it is tempting now to see whether this same pattern holds vis-à-vis the 1930s political situation. Choosing one variable, competitive participation, we do find a similar result (in the 1930s none of the NICs existed so this finding applies only to passive-versus-active Latin America).

The results of this section are, of course, very tentative. Few of the relationships will safely submit to more sophisticated testing, as we push the limits of small sample size and subjective data construction. For the most part I just focus on means and levels of variable and not on a specific econometric model. It is enough to illustrate, I hope, the potential for a political-economy model of macropolicy applied to the periphery just as it has been applied by economic historians studying the core.

\section{Lessons for Today}

This paper tries to carve out a new area of understanding in twentieth century Latin American economic history, focusing on the great shift in policy objectives after the Great Depression. I have argued that peripheral economies were subject to the same kinds of populist pressures seen in the core, and, accordingly, policy outcomes depended to some extent on the political institutional framework that prevailed at the time of the interwar crisis. This is revealed by the heterogeneity of policy response within Latin America, and in the persistence of that response in the postwar period. Even in the 1960s and 1970s, the same patterns were visible in reactive and passive economies, and a comparison with East Asian outcomes only underscores the result.

However, there are certainly sufficient gaps in this analysis to make it only provisional. More research is surely needed on a case by case bases to indentify the links between external constraints, populist pressure, and the mechanics of policy choice. I would also stress that the macroeconomic focus of the paper should not be read as implying an absence of concern for microeconomic foundations. All of the aggregate distortions seen, and the policies behind them, are ultimately built on sets of specific interventions designed to raise transactions costs or otherwise throw sand in the wheels of markets, contracts, and free trading. These fundamental issues echo the literature on transaction costs, incentive structures, and the persistence of imperfect institutions due to interest-group action, rent seeking, path dependence, and so on. Finally, a major issue, beyond the scope of the paper but exceedingly important, concerns the origins of pre-1929 political institutions in determining subsequent outcomes. We must look back further in the political history of Latin America to better understand why the particular forms of democracy, elections, centralization, and 
representation evolved to where they were in the 1920s, and why they varied as they did across space and time. ${ }^{36}$ In this regard we should also mention the problem of distinguishing the present approach from a traditional view based on U.S. foreign policy strength as an external determinant of policy reactions in the 1930s: it is true that the more undemocratic and passive countries tend to be those closest to U.S. influence.

Even with all these caveats, this paper makes a first attempt at extending some ideas of core economic history to the periphery. It must recognize some important distinctions, given the focus on capital markets: in the capital-scarce periphery individuals, groups, and states faced very different costs and benefits from interventions in the capital market. For this reason, the analysis suggested here is in some ways at odds with the core model. ${ }^{37}$

A first implication of the hypothesis suggested here is that we need to make some revisions to our understanding of the balance of internal and external economic and political forces as they affected the evolution of Latin American macropolicies after the 1930. But the intent is not to replace a monocausal externally-oriented theory with a monocausal internally-oriented theory. A role for both is needed. Whilst small semi-open economies like those in the region will never be able to totally escape the implications of global economic forces entirely, it is not necessarily true that this means that economic outcomes are shaped entirely by outside forces. To a very great extent, macropolicies since the 1930s have evolved in line with Díaz Alejandro's passive-reactive categorization, but this evolution is traceable in large part to the nature of domestic political institutions in the various countries. The more reactive economies were those more subject to the kinds of populist pressures that generated greater deviations from the gold standard in the 1930s in the core, suggesting a universal theory of policy reaction in the Depression years in both the core and the periphery. Latin America differed in the way this policy response persisted into the 1970s and 1980s, whereas some other developing countries (for example, the Asian group) were able to reform these policies much sooner.

A second implication is that economists, historians, and political scientists can use the laboratory of economic history to assess the interaction of democratic political tensions and policy outcomes. This is a controversial subject, with influential work arising from economists such as Alberto Alesina, Dani Rodrik, and Robert Barro. Barro's alarming claim that too much democracy

\footnotetext{
${ }^{36}$ On groups, politics, institutions, and growth see Olson (1968; 1982) and North (1990). North has emphasized the long-run impact of centralized, undemocratic Spanish colonial institutions on Latin American development. As we see by the twentieth century, a populist form of politics had evolved in some countries that was important in determining later twentieth century outcomes. See Dornbusch and Edwards (1991).

${ }^{37}$ In the postwar period it would seem that, say, Europe was as susceptible to populist pressure given its democratic foundations. Did postwar Europe fail economically like Latin America? No. But that pressure, as mediated via the trilemma, could not could off vital supplies of foreign capital as in a periphery situation-though by creating other rigidities it could have had important growth-reducing implications in some areas of the economy. See Olson (1982).
} 
may be bad for economic growth is certainly echoed in history, and in more than just a partial correlation of democracy indicators and growth outcomes. Indeed, investigations along the lines of the model suggested here can take us beyond the surface level findings of reduced-form growth empirics and into some of the more detailed mechanisms by which political structure affects policy choices and hence growth.

History is also a key testing ground, and affords a more detailed picture of such a process at work. The policy response of the core in the 1930s was certainly driven by populist pressures demanding an end to the gold standard and the laissez-faire macroeconomic economic orthodoxy of the day, as emphasized by Temin and Eichengreen. ${ }^{38}$ The present paper argues that no less affected in this way were the economies of the periphery. Critical here though was an analysis that did not just end in the 1930s, but which followed the response in the postwar era. Reactive policies were very successful in averting depression in the $1930 \mathrm{~s}$, both in the core and periphery. ${ }^{39}$ But the legacy of the Great Depression and persisted up to fifty or more years in Latin America, and this paper suggest that populism in the realm of domestic politics was a key cause. ${ }^{40}$

It would be an exaggeration, not to say dangerous, to suggest that these results in any way devalue the worth of a democratic society, which has so many non-pecuniary welfare benefits. But history suggests we should not get overoptimistic about the irreversibility of the current wave of economic reform and global integration, both in the core and periphery. We need a real understanding of the potential power of popular will and political means to derail the process, as happened in the 1930s. Recent reforms aim to undo the last sixty years of isolation and reintegrate Latin America into the global economy, but they are not guaranteed to succeed, and face many of the same challenges. For example, in seeking price stability via fixed exchange rates and goldstandard-type currency boards, the economies of Latin America, and now East Asia, are exposing themselves to the full brunt of the macroeconomic trilemma.

Economists have warned for many years of the constraints on growth and efficiency caused by the closure of an economy to outside influences. This message about the constraints of closedness seems to have been appreciated of late by politicians and the public: economic reforms have advanced and the world economy has achieved greater integration. But in the present climate have the constraints of openness been adequately understood by politicians and the public? History teaches us that the choice to embrace globalization, and all the benefits and costs that such a choice entails, has always meant hard choices in times of crisis, and in the present day we should expect no different. Collapsing financial systems, hard monetary rules, and freely mobile capital were all

\footnotetext{
${ }^{38}$ See Eichengreen (1992) and Temin (1989)

${ }^{39}$ See Campa (1990) and Eichengreen and Sachs (1985).

${ }^{40}$ Alesina (1992), Barro (1994) Rodrik (1995; 1996; 1997).
} 
ingredients of an anti-globalization reaction six decades ago. In the end, and under popular pressure, policymakers untied their hands in the 1930s, and have been using them ever since.

All that said, few would say the democratic political process should be sacrificed to evade these tensions. Instead this paper indicates that policymakers, and their constituencies, face a responsibility to find an informed position to understand the short and long-term implications of their actions, and here economic history has its part to play.

\section{References}

Abramovitz, M. 1986. Catching Up, Forging Ahead, and Falling Behind. Journal of Economic History 46 (June): $385-406$.

Alesina, A. et al. 1992. Political Instability and Economic Growth. Working Paper Series no. 4173, National Bureau of Economic Research.

Barro, R. J. 1994. Democracy and Growth. Working Paper Series no. 4909, National Bureau of Economic Research (October).

Barro, R. J., and X. Sala-i-Martin. 1995. Economic Growth. New York: McGraw-Hill.

Baumol, W. 1986. Productivity Growth, Convergence and Welfare: What the Long-Run Data Show. American Economic Review 76 (December): 1072-85.

Blanchard, O. J., and S. Fischer. 1989. Lectures on Macroeconomics. Cambridge, Mass.: MIT Press.

Bratter, H. M. 1939. Foreign Exchange Control in Latin America. Foreign Policy Reports 14 : 274-88.

Bulmer-Thomas, V. 1994. The Economic History of Latin America Since Independence. Cambridge: Cambridge University Press.

Bulmer-Thomas, V. 1996. The Latin American Economies in the 1930s. In The Cambridge History of Latin America, vol. 6, edited by L. Bethell. Cambridge: Cambridge University Press.

Campa, J. M. 1990. Exchange Rates and Economic Recovery in the 1930s: An Extension to Latin America. Journal of Economic History 50 (September): 677-82.

Cardoso, E., and A. Fishlow. 1992. Latin American Development: 1950-1980. Journal of Latin American Studies 24 : 197-218.

Cardoso, E., and A. Helwege. 1992. Latin America's Economy: Diversity Trends and Conflicts. Cambridge, Mass.: MIT Press.

Coatsworth, J. H. 1993. Economic Retardation and Growth in Latin America and Southern Europe Since 1700. Harvard University (December). Photocopy.

Coatsworth, J. H. 1998. Economic and Institutional Trajectories in Pre-Modern Latin America. In Latin America and the World Economy in the Nineteenth and Twentieth Centuries: Explorations in Quantitative Economic History, edited by J. H. Coatsworth and A. M. Taylor. Cambridge: Harvard University Press. Forthcoming.

De Long, J. B., and L. H. Summers. 1991. Equipment Investment and Economic Growth. Quarterly Journal of Economics 106 (May): 445-502.

Díaz Alejandro, C. F. 1984a. The 1940s in Latin America. In Economic Structure and Performance: Essays in Honor of Hollis B. Chenery, edited by M. Syrquin, L. Taylor and L. E. Westphal. Orlando, Fla.: Academic Press.

Díaz Alejandro, C. F. 1984b. Latin America in the 1930s. In Latin America in the 1930s: The Role of the Periphery in World Crisis, edited by R. Thorp. New York: St. Martin's Press.

Dornbusch, R., and S. Edwards, ed. 1991. The Macroeconomics of Populism in Latin America. Chicago: University of Chicago Press.

Dowrick, S., and D.-T. Nguyen. 1989. OECD Comparative Economic Growth 1950-85: Catch-Up and Convergence. American Economic Review 79 (December): 1010-30.

Easterly, W. 1993. How Much Do Distortions Affect Growth? Journal of Monetary Economics 32 : $187-212$.

Edelstein, M. 1982. Overseas Investment in the Age of High Imperialism. New York: Columbia University Press.

Edwards, S. 1992. Trade Orientation, Distortions and Growth in Developing Countries. Journal of Development Economics 39 : 31-57.

Edwards, S. 1995. Crisis and Reform in Latin America: From Despair to Hope. New York: Oxford University Press.

Eichengreen, B. J. 1992. Golden Fetters: The Gold Standard and The Great Depression, 1919-1939. Oxford: Oxford University Press. 
Eichengreen, B. J. 1996. Globalizing Capital: A History of the International Monetary System. Princeton, N.J.: Princeton University Press.

Eichengreen, B. J., and J. D. Sachs. 1985. Exchange Rates and Economic Recovery in the 1930s. Journal of Economic History 45 (December): 925-46.

Einzig, P. 1934. Exchange Control. London: Macmillan.

Engerman, S. L., and K. L. Sokoloff. 1997. Factor Endowments, Institutions, and Differential Paths of Growth Among New World Economies: A View from Economic Historians of the United States. In How Latin America Fell Behind: Essays on the Economic Histories of Brazil and Mexico, 1800-1914, edited by S. Haber. Stanford, Calif:: Stanford University Press.

Fishlow, A. 1971. Origins and Consequences of Import Substitution in Brazil. In International Economics and Development: Essays in Honor of Raúl Prebisch, edited by L. E. D. Marco. New York: Academic Press.

Haber, S., ed. 1997a. How Latin America Fell Behind: Essays on the Economic Histories of Brazil and Mexico, 1800-1914. Stanford, Calif.: Stanford University Press.

Haber, S. 1997b. Introduction: Economic Growth and Latin American Economic Historiography. In How Latin America Fell Behind: Essays on the Economic Histories of Brazil and Mexico, 1800-1914, edited by S. Haber. Stanford, Calif.: Stanford University Press.

Jaggers, K., and T. R. Gurr. 1995. Tracking Democracy's Third Wave with the Polity III Data. Journal of Peace Research $32: 469-482$.

Jones, C. I. 1994. Economic Growth and the Relative Price of Capital. Journal of Monetary Economics 34 : $359-82$.

Levine, R., and D. Renelt. 1992. A Sensitivity Analysis of Cross-Country Growth Regressions. American Economic Review 82 (September): 942-63.

Maddison, A. 1989. The World Economy in the 20th Century. Paris: OECD.

Maddison, A. 1991. Dynamic Forces in Capitalist Development: A Long-Run Comparative View. Oxford: Oxford University Press.

Mankiw, N. G. 1995. The Growth of Nations. Brookings Papers on Economic Activity 1 : 275-310.

Mankiw, N. G., D. Romer, and D. N. Weil. 1992. A Contribution to the Empirics of Economic Growth. Quarterly Journal of Economics 107 (May): 407-37.

North, D. C. 1990. Institutions, Institutional Change, and Economic Performance. Cambridge: Cambridge University Press.

Obstfeld, M., and A. M. Taylor. 1998. The Great Depression as a Watershed: International Capital Mobility in the Long Run. In The Defining Moment: The Great Depression and the American Economy in the Twentieth Century, edited by M. D. Bordo, C. D. Goldin and E. N. White. Chicago: University of Chicago Press.

Olson, M., Jr. 1968. The Logic of Collective Action: Public Goods and the Theory of Groups. New York: Schoken Books.

Olson, M., Jr. 1982. The Rise and Decline of Nations: Economic Growth, Stagflation, and Social Rigidities. New Haven, Conn.: Yale University Press.

Pack, H. 1994. Endogenous Growth: Intellectual Appeal and Empirical Shortcomings. Journal of Economic Perspectives 8 (Winter): 55-72.

Rodrik, D. 1995. Getting Interventions Right: How South Korea and Taiwan Grew Rich. Economic Policy (April).

Rodrik, D. 1996. Coordination Failures and Government Policy: A Model with Applications to East Asia and Eastern Europe. Journal of International Economics 40 : 1-22.

Rodrik, D. 1997. Trade Strategy, Investment and Exports: Another Look at East Asia. Pacific Economic Review (February).

Romer, P. M. 1994. The Origins of Endogenous Growth. Journal of Economic Perspectives 8 (Winter): 3-22.

Sachs, J. D., and A. M. Warner. 1995. Economic Reform and the Process of Global Integration. Brooking Papers on Economic Activity : 1-118.

Solow, R. M. 1956. A Contribution to the Theory of Economic Growth. Quarterly Journal of Economics 70 (February): 65-94.

Taylor, A. M. 1992. External Dependence, Demographic Burdens and Argentine Economic Decline After the Belle Époque. Journal of Economic History 52 (December): 907-36.

Taylor, A. M. 1994a. Three Phases of Argentine Economic Growth. Working Paper Series on Historical Factors in Long Run Growth no. 60, National Bureau of Economic Research (October).

Taylor, A. M. 1994b. Tres fases del crecimiento económico argentino. Revista de Historia Económica 12 (Otoño): 649-683.

Taylor, A. M. 1998. On the Costs of Inward-Looking Development: Price Distortions, Growth, and Divergence in Latin America. Journal of Economic History 58 (March): 1-28.

Temin, P. 1989. Lessons from The Great Depression. Cambridge, Mass.: MIT Press. 
Thorp, R. 1992. A Reappraisal of the Origins of Import-Substituting Industrialisation: 1930-1950. In The Colonial and Post-colonial Experience: Five Centuries of Spanish and Portuguese America, edited by T. Halperín Donghi. Journal of Latin American Studies, Quincentenary Supplement Cambridge: Cambridge University Press.

Twomey, M. J. 1998. Patterns of Foreign Investment in the Third World in the Twentieth Century. In Latin America and the World Economy in the Nineteenth and Twentieth Centuries: Explorations in Quantitative Economic History, edited by J. H. Coatsworth and A. M. Taylor. Cambridge: Harvard University Press.

Williamson, J. G. 1996. Globalization, Convergence, and History. Journal of Economic History 56 (June): 277-306.

Yeager, L. B. 1976. International Monetary Relations: Theory, History, and Policy. 2d ed. New York: Harper and Row. 
To order any of these papers in hard copy, see instructions at the end of this list. To subscribe to all NBER Working Papers or the papers in a single area, see instructions inside the back cover.

Number

7342

7343

7344

7345

7346

7351

7352

7353

7354

7355

7356
Author(s)

David C. King

Richard J. Zeckhauser

Christina Paxson

Jane Waldfogel

Michael Hout

Harvey S. Rosen

Jean O. Lanjouw

Mark Schankerman

Geert Bekaert

Steven R. Grenadier

Thomas N. Hubbard

Jonathan Gruber

Edward P. Lazear

Tamim Bayoumi

Taizo Motonishi

Hiroshi Yoshikawa

Daron Acemoglu

Robert Shimer

Jeff Grogger

Charles Michalopoulos

Roberto Rigobon

Ricardo J. Caballero

Mohamad L. Hammour

Alec Ian Gershberg

Michael Grossman

Fred Goldman $\underline{\text { Title }}$

Congressional Vote Options

$9 / 99$

Work, Welfare, and Child Maltreatment

$9 / 99$

Self-Employment, Family Background, and Race

$9 / 99$

The Quality of Ideas: Measuring Innovation with

9/99

Multiple Indicators

Stock and Bond Pricing in an Affine Economy

$9 / 99$

How Wide Is the Scope of Hold-Up-Based Theories?

$9 / 99$

Contractual Form and Market Thickness in Trucking

The Wealth of the Unemployed: Adequacy and

$9 / 99$

Implications for Unemployment Insurance

Educational Production

$9 / 99$

The Morning After: Explaining the Slowdown in Japanese Growth in the 1990s

$9 / 99$

Causes of the Long Stagnation of Japan during the

$9 / 99$

1990's: Financial or Real?

Productivity Gains From Unemployment Insurance

9/99

Welfare Dynamics under Time Limits

$9 / 99$

On the Measurement of the International Propagation

$9 / 99$ of Shocks

The Cost of Recessions Revisited: A ReverseLiquidationist View

Competition and the Cost of Capital Revisited: Special Authorities and Underwriters in the Market for Taxexempt Hospital Bonds

You can download these and other papers at the NBER Web site:

Free searchable abstracts are also available at the site. 
To order any of these papers in hard copy, see instructions at the end of this list. To subscribe to all NBER Working Papers or the papers in a single area, see instructions inside the back cover.

Number $\quad \underline{\text { Author(s) }}$

$\underline{\text { Title }}$

Date

Robert E. Lipsey

7358

7359

7360

7361

7362

7363

7364

7365

7366

7367

7368

7369

7370

Harvey S. Rosen
Vernon Henderson

Iain Cockburn

Rebecca Henderson

Scott Stern

Douglas Holtz-Eakin

John W. Phillips

Bong-Chan Kho

René $\mathrm{M}$. Stulz

Jagadeesh Gokhale

Laurence J. Kotlikoff

Bruce D. Meyer

Dan T. Rosenbaum

Dani Rodrik

Andrés Velasco

Michael D. Bordo

Lars Jonung

Emmanuel Saez

Emmanuel Saez

Alan L. Gustman

Thomas L. Steinmeier

Wolfgang Keller

Arik Levinson

Michael Baker

Gary Solon
Foreign Production by U.S. Firms and Parent Firm

$9 / 99$

Employment

Marshall's Economies

$9 / 99$

The Diffusion of Science-Driven Drug Discovery:

$9 / 99$

Organizational Change in Pharmaceutical Research

Estate Taxes, Life Insurance, and Small Business

9/99

Banks, the IMF, and the Asian Crisis

$9 / 99$

Social Security's Treatment of Postwar Americans:

$9 / 99$

How Bad Can It Get?

Welfare, the Earned Income Tax Credit, and the

$9 / 99$

Labor Supply of Single Mothers

Short-Term Capital Flows

$9 / 99$

The Future of EMU: What Does the History of $9 / 99$ Monetary Unions Tell Us?

Do Taxpayers Bunch at Kink Points?

$9 / 99$

The Effect of Marginal Tax Rates on Income: A Panel Study of 'Bracket Creep'

What People Don't Know About Their Pensions $9 / 99$ and Social Security: An Analysis Using Linked Data From The Health and Retirement Study

Environmental Compliance Costs and Foreign Direct Investment Inflows to U.S. States

Earnings Dynamics and Inequality among Canadian Men, 1976-1992: Evidence from Longitudinal Income Tax Records

You can download these and other papers at the NBER Web site:

Free searchable abstracts are also available at the site. 
To order any of these papers in hard copy, see instructions at the end of this list. To subscribe to all NBER Working Papers or the papers in a single area, see instructions inside the back cover.

Number

7371

7372

7373

7374

7375

7376

7377

7378

7379

7380

7381

7382

7383
Author(s)

Michael Baker

Nicole M. Fortin

B. Douglas Bernheim

Lorenzo Forni

Jagadeesh Gokhale

Laurence J. Kotlikoff

Paul A. David

Bronwyn H. Hall

Andrew A. Toole

Peter Cappelli

David Neumark

Charles I. Jones

Harrison Hong

Jeremy C. Stein

George Chacko

Luis M. Viceira

Bruce A. Blonigen

Stephen E. Haynes

Victor R. Fuchs

Michael D. Hurd

James P. Smith

Olivia S. Mitchell

Michael B. Devereux

Charles Engel

Cedric Tille

Stephen L. Mehay

Rosalie Liccardo Pacula $\underline{\text { Title }}$

Date

Occupational Gender Composition and Wages in Canada: 9/99 1987-1988

The Adequacy of Life Insurance: Evidence from the

$10 / 99$ Health and Retirement Survey

Is Public R\&D a Complement or Substitute for Private

$10 / 99$

R\&D? A Review of the Econometric Evidence

Do "High Performance" Work Practices Improve

$10 / 99$ Established-Level Outcomes?

Was an Industrial Revolution Inevitable?

$10 / 99$

Economic Growth Over the Very Long Run

Differences of Opinion, Rational Arbitrage

$10 / 99$ and Market Crashes

Dynamic Consumption and Portfolio Choice with Stochastic Volatility in Incomplete Markets

Antidumping Investigators and the Pass-Through of

$10 / 99$

Exchange rates and Antidumping Duties

The Future of Health Economics

$10 / 99$

Anticipated and Actual Bequests

New Trends in Pension Benefit and

$10 / 99$

Retirement Provisions

Exchange Rate Pass-through and the Welfare Effects of the Euro

The Effectiveness of Workplace Drug Prevention

$10 / 99$

You can download these and other papers at the NBER Web site:

Free searchable abstracts are also available at the site. 
To order any of these papers in hard copy, see instructions at the end of this list. To subscribe to all NBER Working Papers or the papers in a single area, see instructions inside the back cover.

\begin{tabular}{|c|c|}
\hline Number & Author(s) \\
\hline 7384 & $\begin{array}{l}\text { Michael Klein } \\
\text { Giovanni Olivei }\end{array}$ \\
\hline 7385 & $\begin{array}{l}\text { Jean Abraham } \\
\text { Ashish Arora } \\
\text { Martin Gaynor } \\
\text { Douglas Wholey }\end{array}$ \\
\hline 7386 & $\begin{array}{l}\text { Gerardo della Paolera } \\
\text { Alan M. Taylor }\end{array}$ \\
\hline 7387 & $\begin{array}{l}\text { Alberto Alesina } \\
\text { Stephen Danninger } \\
\text { Massimo V. Rostagno }\end{array}$ \\
\hline 7388 & $\begin{array}{l}\text { Oliver Hart } \\
\text { John Moore }\end{array}$ \\
\hline 7389 & $\begin{array}{l}\text { Joshua Aizenman } \\
\text { Nancy Marion }\end{array}$ \\
\hline 7390 & $\begin{array}{l}\text { David M. Cutler } \\
\text { Ellen Meara }\end{array}$ \\
\hline 7391 & Joel Waldfogel \\
\hline 7392 & $\begin{array}{l}\text { James M. Poterba } \\
\text { Andrew A. Samwick }\end{array}$ \\
\hline 7393 & Bennett T. McCallum \\
\hline 7394 & Alan M. Taylor \\
\hline
\end{tabular}

$\underline{\text { Title }}$

$\underline{\text { Date }}$

Capital Account Liberalization, Financial Depth and

$10 / 99$

Economic Growth

Enter at Your Own Risk: HMO Participation and

$10 / 99$

Enrollment in the Medicare Risk Market

Internal Versus External Convertibility and Developing- 10/99 Country Financial Crises: Lessons from the Argentine

Bank Bailout of the 1930's

Redistribution Through Public Employment: The Case 10/99 of Italy

On the Design of Hierarchies: Coordination Versus

$10 / 99$ Specialization

Uncertainty and the Disappearance of International $\quad 10 / 99$ Credit

The Technology of Birth: Is it Worth It?

$10 / 99$

Preference Externalities: An Empirical Study of Who

$10 / 99$ Benefits Whom in Differentiated Product Markets

Taxation and Household Portfolio Composition: U.S. 10/99 Evidence from the 1980 's and 1990 's

Theoretical Issues Pertaining to Monetary Unions

$10 / 99$

Latin America and Foreign Capital in the Twentieth

$10 / 99$

Century: Economics, Politics, and Institutional Change

Copies of the above working papers can be obtained for $\$ 10.00$ per copy (plus $\$ 10.00$ per order for shipping for all locations outside the continental U.S.) to Working Papers, NBER, 1050 Massachusetts Avenue, Cambridge, MA 02138-5398. Pre-payment is required on all orders and may be made by check or credit card. Checks should be made payable to the NBER and must be in dollars drawn on a U.S. bank. If paying by credit card, include the cardholder's name, account number, and expiration date. For all orders, please be sure to include your return address and telephone number. Working papers may also be ordered by telephone (868-3900), fax (617-868-2742), or email (orders@) nber.org).

You can download these and other papers at the NBER Web site:

www.nber.org

Free searchable abstracts are also available at the site. 